\title{
Electro-ozonizers: a new approach for an old problem
}

\author{
J.A. Lara-Ramos ${ }^{1}$, C. Saez ${ }^{2}$, F. Machuca-Martínez ${ }^{1}$, M.A. Rodrigo ${ }^{2 *}$ \\ ${ }^{1}$ Escuela de Ingeniería Química, Universidad del Valle, Cali, Colombia. \\ ${ }^{2}$ Departamento de Ingeniería Química. Facultad de Ciencias y Tecnologías Químicas. \\ Universidad de Castilla La Mancha. Campus Universitario s/n 13071 Ciudad Real. Spain.
}

\begin{abstract}
This work focuses on the electrochemical production of ozone and its use in the degradation of pollutants contained in wastewater. To do this, the production of ozone by two commercial electrochemical cells specially designed to produce ozone (manufactured by CONDIAS $\mathrm{GmbH}$ ) is compared, as well as their performance in the treatment of a synthetic wastewater containing Clopyralid. This treatment is also evaluated with ozone supplied by a conventional ozone generator. Results demonstrate that polymer exchange membrane (PEM) electrolyzers can produce efficiently ozone, which is consumed in the degradation of pollutants, although other oxidative pathways develop simultaneously, being co-responsible of the high efficiencies obtained. In comparing results, it was found a lower consumption of electrical energy in the production of ozone and a higher degradation and mineralization with electrochemical cells. A high percentage of the ozone produced by the electrochemical cell is used to replace the dissolved ozone that has reacted.
\end{abstract}

\section{Keywords}

Electro-ozonator; ozone; electrolysis; clopyralid; operation mode 


\section{Highlights}

- Ozone can be produced electrochemically using PEM electrolyzer

- Ozone supplies in the rate $10^{-4}-10^{-3} \mathrm{~g} \mathrm{~h}^{-1} \mathrm{~cm}^{-2}$ of BDD anodes

- Clopyralid is efficiently degraded and mineralized using ozone

- Continuous mode is less efficient than batch operation for ozone production

*corresponding author: manuel.rodrigo@uclm.es 


\section{Introduction}

Treatment of wastewater is a topic of the major significance [1]. When wastewater is polluted with hazardous anthropogenic pollutants, conventional treatments are not always useful. In that context, advanced oxidation processes (AOPs), based on the production and use of hydroxyl radicals, have demonstrated their suitability and even their outstanding performance for facing this serious environmental problem [2, 3]. Among the EAOPs, it is worth to highlight ozonation and electrolysis. The first is based on the production and activation of ozone[4-7], while in the second, a cocktail of oxidants can be formed and activated because of the oxidation and/or reduction of components of the wastewater [8, 9]. Thus, in electrochemically-based processes, in addition to ozone, many other species can be formed such as the cathodically generated hydrogen peroxide or the anodically generated chlorine, peroxocarbonates, peroxosulfates, etc. This explains the high efficiencies obtained by this technology in the treatment of various pollutants ranging from dyes $[10,11]$ to pesticides [12] passing through many other anthropogenic pollutants [13-15].

Doped diamond coating materials have been proposed as anodes in electrochemical cells since the nineties[16, 17]. They have shown outstanding features such as an extremely large electrochemical window, which is responsible for their outstanding capacity for the production of oxidants, as difficult to be obtained as peroxophosphates, peroxocarbonates of perbromates [18-20]. Because of that, in using these materials for the treatment of wastewater, it is common that the mechanisms used to explain the degradation of organics do not only consider the direct oxidation by electron transfer on the anode surface but, most likely, the mediated oxidation by a large variety of oxidants formed from the different salts

contained in the electrolyte, as well as ozone and hydrogen peroxide [21]. This becomes a 
problem in disinfection because of the potential production of hazardous perchlorate [22, 23], but it is a very positive input in the electrolysis of wastewater [24].

Ozone is a strong oxidant used in water disinfection, that a step has been taken in the application of wastewater treatment in conventional treatment plants. However, one of the greatest difficulties of ozonation is the transfer of mass between the gaseous and liquid phase. For this reason different configurations and types of reactors have been designed in order to increase the amount of ozone in solution, another difficulty is the low percentages of mineralization of organic matter because of its low selectivity [25]. In-situ electrochemical ozone generation could have a better mass transfer and mineralization efficiency for the wastewater treatment.

Regarding the electrochemical production of ozone, although basically described in many works, it seems that it is not as interesting as other ways of preparing these oxidants and there are many flanks to be studied [15, 26, 27]. This may help to explain the low introduction of the technology in the market, despite the huge potentiality of the application that it may have associated. In part, this low efficiency is explained in terms of the low solubility of oxygen (ozone precursor), which in turn may be responsible for promoting other side reactions in the electrochemical cell. Anyway, this topic is of great commercial interest due to the important application it can have in water disinfection. Because of that, there are many commercial prototypes, most of them based on the use of polymer exchange membrane (PEM) electrolyzers such as the two cells evaluated in this work, manufactured by CONDIAS $\mathrm{GmbH}$, and which have demonstrated a good performance in their use as electro-disinfectors [29-30]. Anyway, regardless of the existence of these interesting cells, a deeper understanding of the process is still a major challenge [31] 
Taking into account this background, the goal fixed for this study is the evaluation of the performance of two commercial PEM electrolyzers in the production of ozone and in the use of this electogenerated ozone to degrade clopyralid, chlorinated hydrocarbon herbicide used in this work as model pollutant. Results obtained by the electrochemical method are compared with those that are reached with the dose of ozone manufactured by a conventional method in order to determine the main differences of the processes and to shed light on the changes that should be made in order to increase the technology readiness level of electroozonation processes.

\section{Material and methods}

Chemicals. Clopyralid (solubility at $25^{\circ} \mathrm{C}=0.52 \mathrm{mM}, \log \mathrm{K}_{\mathrm{ow}}=1.06$ ) used to prepare synthetic groundwater was analytical grade ( $>99.0 \%$ purity) and supplied by Sigma-Aldrich Laborchemikalien GmbH (Steinheim, Germany).

Electrochemical cell and ozone generator. Electrolyses were carried out in two cells $\mathrm{CabECO}{ }^{\circledR}$ and $\mu \mathrm{ZON} \circledast$ equipped with diamond electrodes, manufactured by CONDIAS (Itzehoe, Germany). The cells were connected to the water reservoir by a centrifugal pump (Masterflex L/S Economy Variable-Speed) and powered by a power supply 30V-5A (Delta Elektronika). The outlet of the cell was recirculated to the water reservoir for the discontinuous tests and to pump to another different tank for the continuous tests. An experimental assembly scheme is shown in Figure 1. 


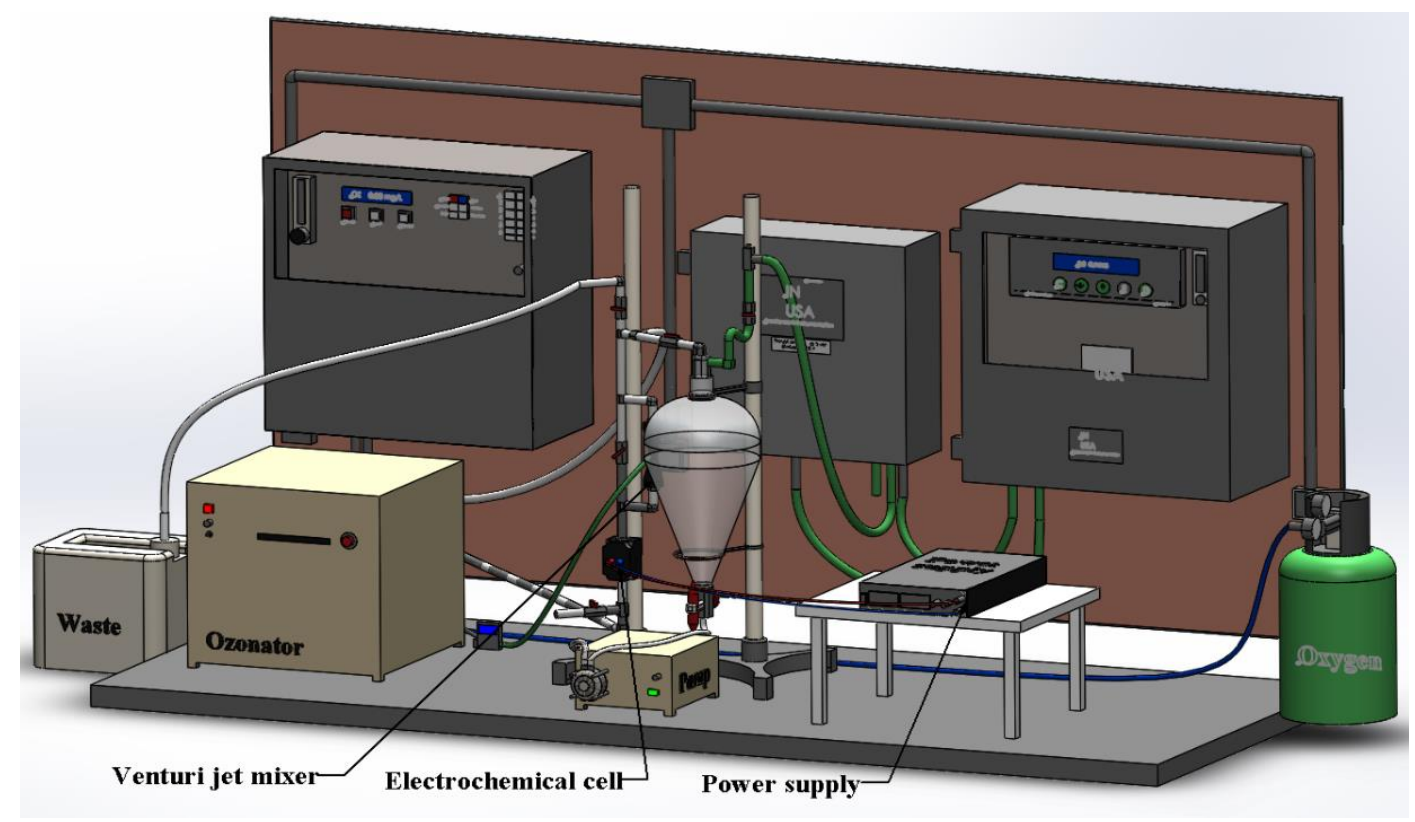

Figure 1. Reaction System Scheme

Ozonation experiments were carried out by continuously feeding an ozone/oxygen gas stream to the system by means of a venturi jet mixer. The experimental setup consisted of an ozone generator Ambizon (Model GMF-10, Sistemas y Equipos de Ozonización S.L., Madrid, Spain), whose maximum production is $10 \mathrm{~g} \mathrm{~h}^{-1}$ ozone. The required oxygen (commercial grade, 99.99\%) and the electric power consumed were $0.14 \mathrm{~m}^{3} \mathrm{~h}^{-1}$ and 1500 watts, respectively.

Analytical techniques. Concentration of ozone in liquids was measured using Spectroquant Merck test kits based on the N,N-diethyl-p-phenylenediamine (DPD) colorimetric method (Hach, Model: DR2000). To analyze the concentration of ozone in the gas stream, an analyzer (IN USA Incorporated model $\mathrm{H} 1-\mathrm{X}$ ) has been used together with a sample conditioning system, which has a measurement range of 0 to $200 \mathrm{~g} \mathrm{~m}^{-3}$ (precision $\pm 0.1 \mathrm{~g} \mathrm{~m}^{-3}$ ). The concentration of clopyralid and the generated intermediates were measured by HPLC-DAD (Agilent 1260 Infinity). The detection wavelength was 280 and the column temperature was 
$30^{\circ} \mathrm{C}$. The volume injection was set at $20 \mu \mathrm{L}$, and a Phenomenex Gemini $5 \mu \mathrm{m} \mathrm{C} 18$ analytical column was used. The mobile phase used was water (containing $0.1 \%$ formic acid)/methanol $(70 / 30, \mathrm{v} / \mathrm{v})$ with a flow rate of $1 \mathrm{~cm}^{3} \mathrm{~min}^{-1}$. The samples extracted from the electrolyzed solutions were filtered with $0.45 \mu \mathrm{m}$ Nylon filters before analysis. The Total Organic Carbon (TOC) concentration was monitored using a Multi N/C 3100 Analytik Jena TOC analyzer.

Experimental procedure. Electrochemical tests were carried out galvanostatically by applying current densities in the range 0.0416 and $0.88 \mathrm{~A} \mathrm{~cm}^{-2}$, working under continuous and discontinuous operation mode. The $\mathrm{O}_{3} / \mathrm{O}_{2}$ mixture that exits the generator can be either conducted to the gas phase ozone analyzer or introduced into the reactor. Ozone that does not dissolve or does not react in the reactor, leaves it and enters an ozone analyzer, which determines the concentration of residual ozone in the gas phase.

\section{Results and discussion}

Figure 2 shows the changes in the ozone concentration contained in the treated liquid during the electrogeneration of ozone using the two types of electrochemical PEM cells studied in this work $(\mathrm{CabECO} \AA$ and $\mu \mathrm{ZON} \circledast)$ and the conventional non-electrochemical ozonator. Tests were carried out in the presence and absence of clopyralid (CP), operating the reactor in discontinuous mode. It can be seen that both, in presence or absence of $\mathrm{CP}$, the highest concentrations of dissolved ozone are achieved by CabECO® cell, while the $\mu \mathrm{ZON}{ }^{\circledR}$ produces similar quantities to that of the conventional ozonizer and in the same magnitude order of $\mathrm{CabECO}{ }^{\circledR}$. Under the presence of $\mathrm{CP}$ the concentration of ozone drops drastically with the ozonator and $\mu \mathrm{ZON}{ }^{\circledR}$ cell, while using the $\mathrm{CabECO} \AA$ cell this change is less important. Despite ozone generation is similar, the energy consumption of the three devices is quite different. Thus, $\mathrm{CabECO}{ }^{\circledR}$ cell exhibited the lower energy consumption $(6.91 \mathrm{~W})$, 
followed by $\mu \mathrm{ZON} \circledast$ cell $(18.47 \mathrm{~W})$ and the conventional ozonator $(45 \mathrm{~W})$. Taking into account the amounts of ozone produced, this is the same order of efficiencies. According to these values, it seems to be more efficient in the electrochemical production of ozone. In addition, cell design has a paramount significance on the results obtained, because CabECO® produces more ozone at three-times lower energy consumptions. Regarding the differences observed with the presence of organics, they have to be related to the degradation of the pollutant and explained in terms of the interaction of the dissolved ozone with the organic molecules and in terms of the occurrence of other reactive pathways.

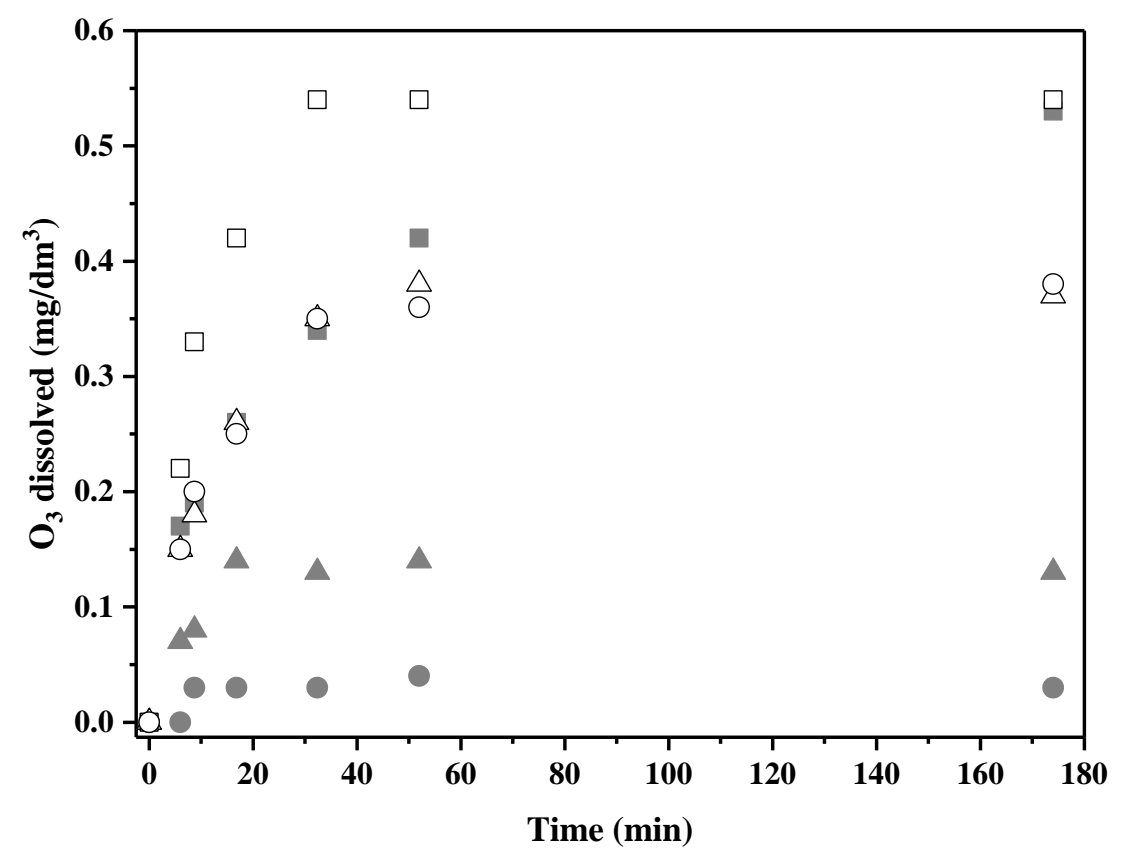

Figure 2. Ozone dissolved in discontinuous mode for $\mu \mathrm{ZON}{ }^{\circledR}$ (triangle), $\mathrm{CabECO}{ }^{\circledR}$ (square) and ozonator (circle), in the presence of $100 \mathrm{mg} / \mathrm{dm}^{3}$ of CP (gray symbol) and absence of CP (empty symbol).

Thus, Figure 3 shows the degradation of $\mathrm{CP}$ and mineralization percentages as a function of time in the discontinuous degradation process. It can be seen that $\mu \mathrm{ZON} \circledast$ cell has a better performance than $\mathrm{CabECO} \AA$ cell and the ozonator. This is important because $\mu \mathrm{ZON} \circledast$ and 
CabECO ${ }^{\circledR}$ cells were operated in the same conditions of current intensity, solution volume and volumetric flow. Up to about 50 minutes of reaction, CabECO® cell attains higher degradation and mineralization of CP. However, after that its performance decreases due to diffusional limitations. On contrary, the ozonator is not able to degrade or mineralize CP.

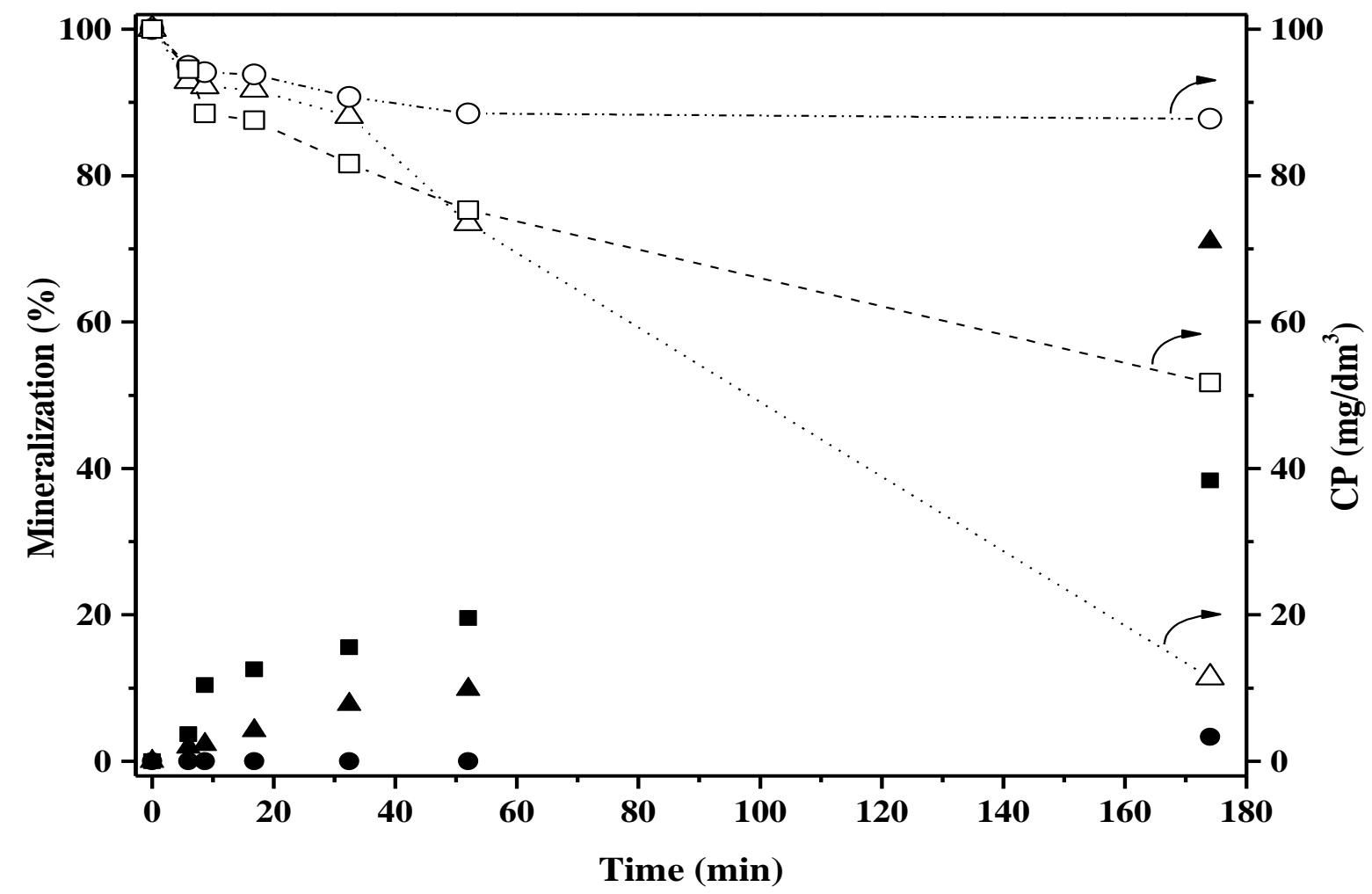

Figure 3. Mineralization (full symbols) and CP transformations (empty symbols) during electrochemical ozonation $\left(\mu \mathrm{ZON} \AA \Delta, \triangle\right.$ and $\left.\mathrm{CabECO}{ }^{\circledR} \boldsymbol{\square}, \square\right)$ and physicochemical ozonation $(\bullet, \circ)$, under discontinuous operation mode

In Figure 4, it is shown the concentration of the by-products generated by the conventional ozonator and the two electro-ozonizers ( $\mathrm{CabECO}{ }^{\circledR}$ and $\left.\mu \mathrm{ZON}{ }^{\circledR}\right)$. As seen, the formation of intermediates is very low. However, it is significantly higher in the non-electrochemical ozonation test, as compared to the $\mathrm{CabECO} \circledast$ and $\mu \mathrm{ZON} ®$ cells. This is in agreement with 
the lower mineralization observed in that case. On the other hand, the lowest concentration of intermediates were obtained using $\mu \mathrm{ZON} \circledast$ cell, which explains the results obtained in the degradation and mineralization of CP. The lower occurrence of intermediates and the favoured mineralization is an important feature of the electrolytic AOPs. This is explained in terms of synergistic combination of different types of oxidants electrogenerated on the surface of the electrodes during the treatment process.

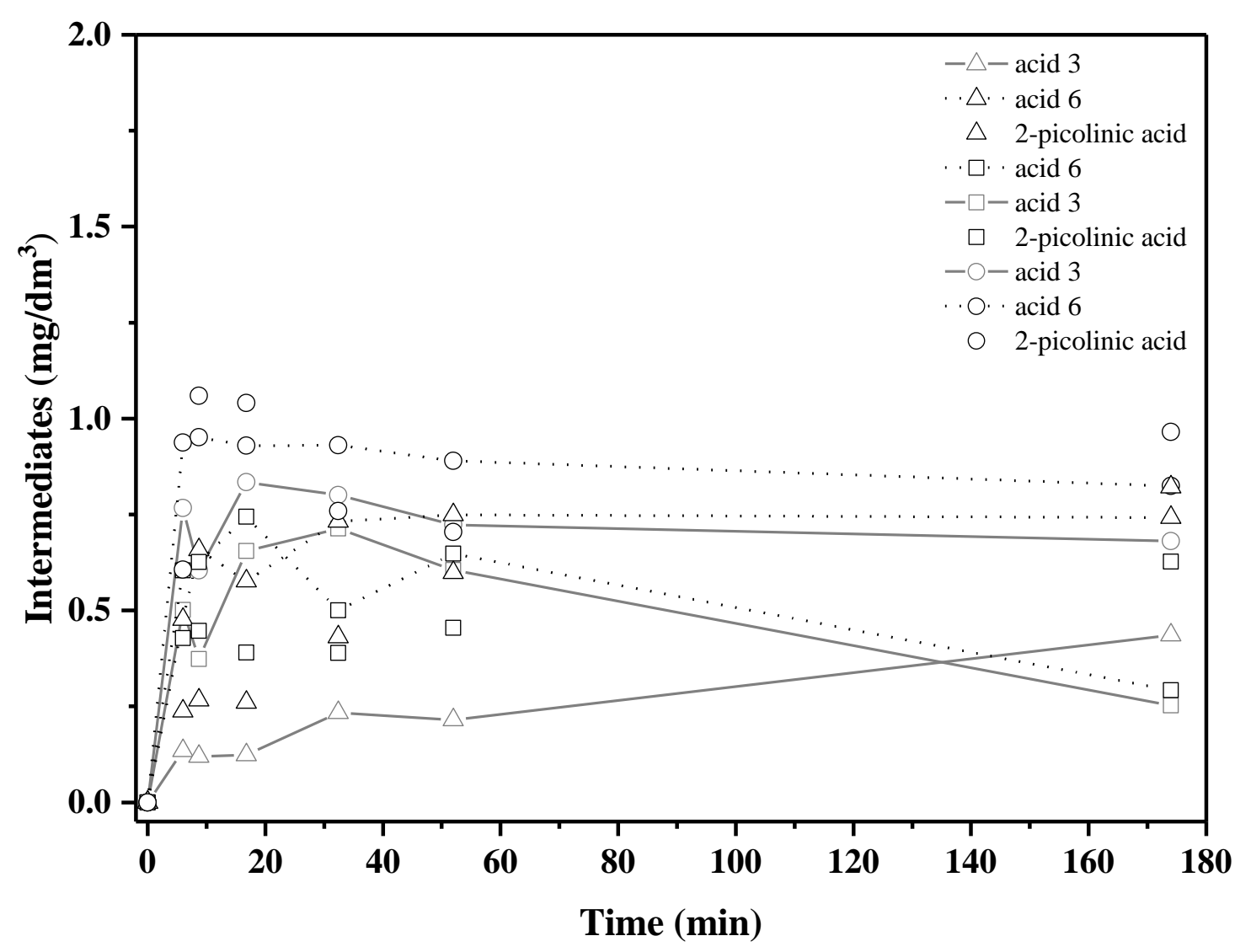

Figure 4. Evolution of intermediates throughout the discontinuous process for physicochemical $(\circ)$ and electrochemical ( $\mu \mathrm{ZON} ® \triangle$, CabECO® $\square$ ) ozonation.

Figure 5 compares the performance of the electro-ozonators in continuous and discontinuous operation mode. As seen, ozone increases in both cases up to a stable concentration, which 
is reached at $1-2 \mathrm{Ah} / \mathrm{dm}^{3}$, both in discontinuous and continuous processes. In addition, it can be observed that discontinuous operation mode leads to higher concentrations of ozone.

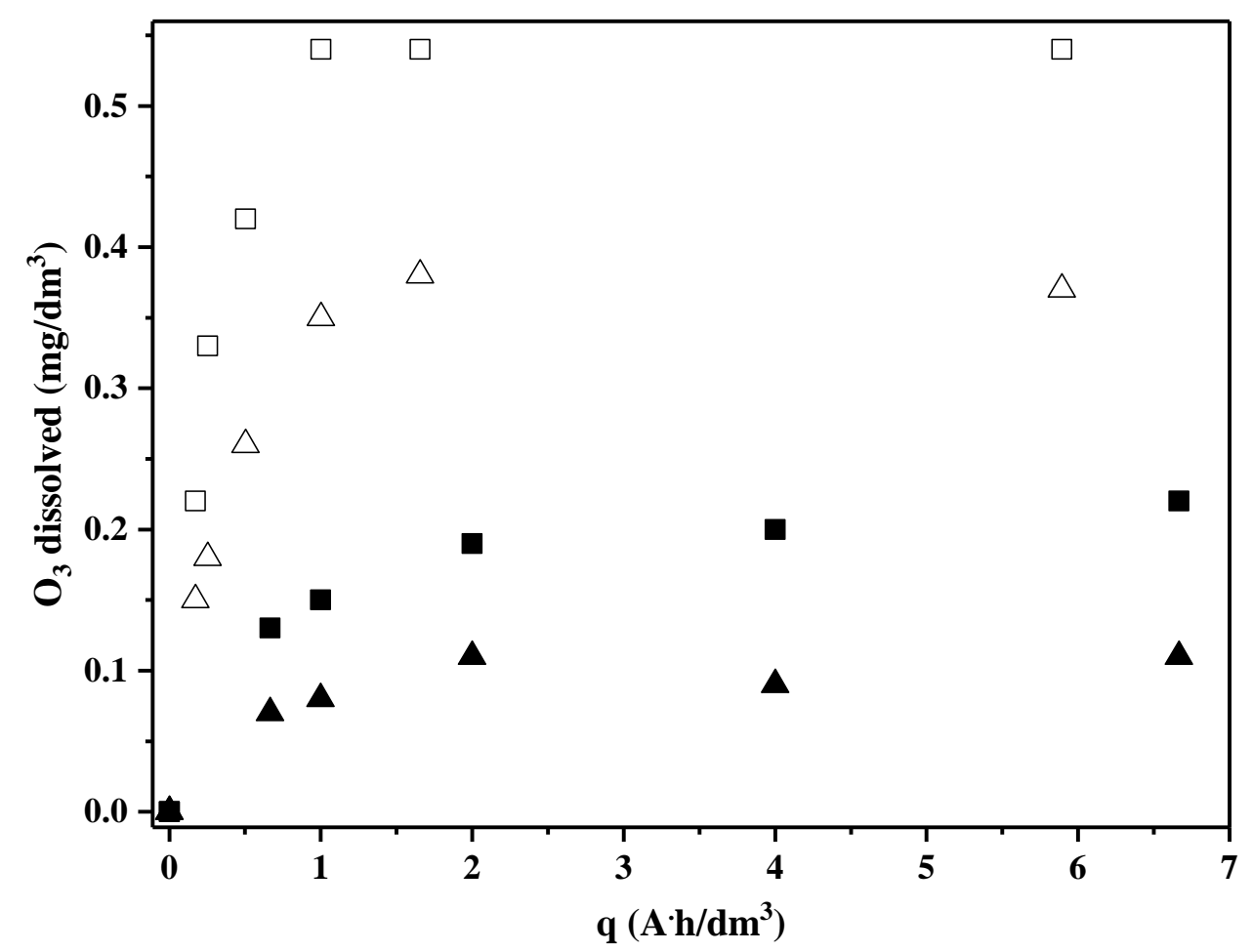

Figure 5. Ozone dissolved from electrochemical generation $\mu \mathrm{ZON} \circledast(\triangle, \mathbf{\Delta})$ and CabECO® $(\square, \mathbf{\square})$ under discontinuous conditions (empty symbols) and continuous (full symbols).

This can be explained by taking into account that in batch mode the electrolytic liquid is recirculated continuously, while in the continuous mode the liquid only passes one time throughout the cell. As a consequence, the plateau reached in the concentration in continuous and discontinuous operation mode has different meanings. In the case of the discontinuous operation, this plateau is an equilibrium between the ozone formed and the ozone transferred to atmosphere or wasted in side reactions. Otherwise, a continuous increase in the concentration would be observed. Meanwhile, in the case of the continuous process, liquid 
is not recirculated into the cell but it only passes one time. This means less interaction with the electrode surface (lower contact time) but it does not exclude the transfer of ozone to atmosphere and the waste of this valious oxidant in side reactions.

To know more about this interesting point, the net ozone production rates were determined by fitting experimental data to equations (1) and (2), which corresponds to simplified mass balances of the two experimental systems in discontinuous and continuous mode, respectively. In these equations, $\boldsymbol{r}_{O_{3}}$ is the net ozone production rates $\mathrm{mg} / \mathrm{min}, Q$ is the continuous flow $\mathrm{dm}^{3} / \mathrm{min}, C_{O_{3}}$ is the ozone concentration in $\mathrm{mg} / \mathrm{dm}^{3}$ (in a given time for the discontinuous and in conditions of stable for continuous), $V$ is the volume of solution in $\mathrm{dm}^{3}$, $t$ is the time in min and $\Delta t$ is an increase in time in min. This fitting has been made for the two cells evaluated.

$$
\begin{aligned}
& \boldsymbol{r}_{O_{3}}=\frac{C_{O_{3,(t+\Delta t)}}-C_{O_{3,(t)}}}{\Delta t} \cdot V \\
& \boldsymbol{r}_{O_{3}}=Q \cdot C_{O_{3}}
\end{aligned}
$$

Figure 6 shows the changes undergone by net ozone production rate during the electrolysis of electrolytes without (part a) and with CP (part b) in discontinuous and continuous operation modes. 

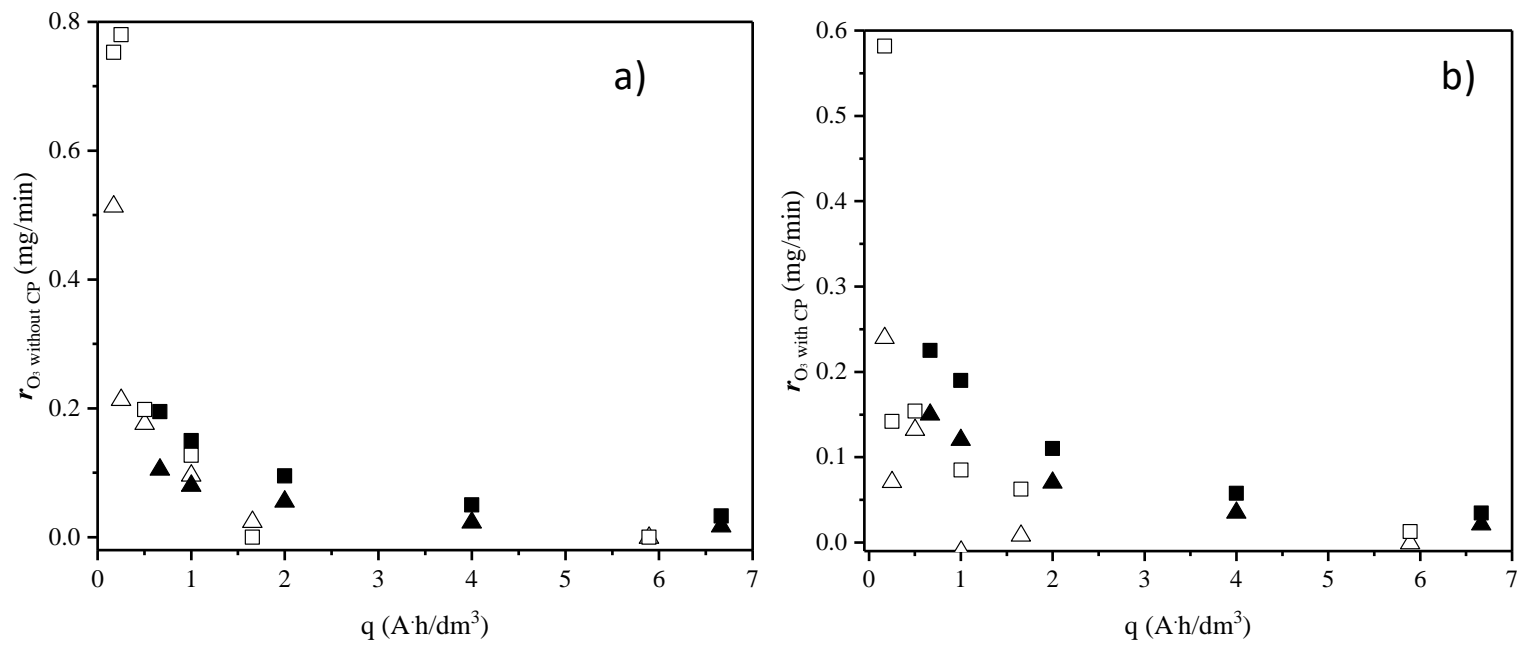

Figure 6. Ozone dissolution rate in the presence (part a) and absence (part b) of CP for ozone electrogeneration in discontinuous (empty symbols) and continuous (full symbols).

It can be seen that the net ozone production rates in the absence of $\mathrm{CP}$ are much higher at the beginning of the discontinuous process. This informs about the convenience of longer contact times between the electrodes and the electrolytes which in the discontinuous process are reached by recirculation. However, the decrease produced in the rate during the process is also much important for the discontinuous process and after $2 \mathrm{~A} \cdot \mathrm{h} / \mathrm{dm}^{3}$, the net rate is higher for the continuous process. This decrease is not only produced by the transfer of ozone to atmosphere (which is promoted by higher values in the solution) but most likely because of the interations of ozone with other oxidants (also present in the continuous operation mode and responsible of the decay observed) and with the electrodes (which is going to be more important in the discontinuous operation). In comparing the two cells, a higher value is found for the CabECO® cell, which can be explained in terms of the lower current density associated to its higher surface area. Thus, both cells were operated under the same current intensity although the surface area of $\mathrm{CabECO}{ }^{\circledR}$ is 21 times higher than that of $\mu \mathrm{ZON} \AA$. This obblies this later cell to operate at extremely high current densities which may promote 
more efficiently side processes to waste the ozone generated by combination with other oxidants formed anodically at such harsh conditions. In comparing the net production rates in the presence and absence of $\mathrm{CP}$, lower values can be observed in the later case due to the consumption of ozone in the degradation of CP.

Thus, Figure 7 shows the difference between the net production of ozone with and without clopyralid in the solution, which has to be related to the ozone consumed in its degradation. It also shows the mineralization observed for this molecule. Trends in the mineralization rate are similar to the changes in degradation and mineralization observed in Figure 3, as expected. Anyway, three important points have to be highlighted:

1) The discontinuous process is more efficient than the continuous process, despite the higher net production of ozone at large current charges in the second case.

2) The $\mu \mathrm{ZON} \otimes$ is more efficient than the $\mathrm{CabECO}{ }^{\circledR}$ cell and this is reflected in both, the ozone consumption and the mineralization rates.

3) Mineralization rates are much higher than those which can be directly explained by ozone consumption, pointing out the relevance of other oxidation mechanisms that develop in the cells
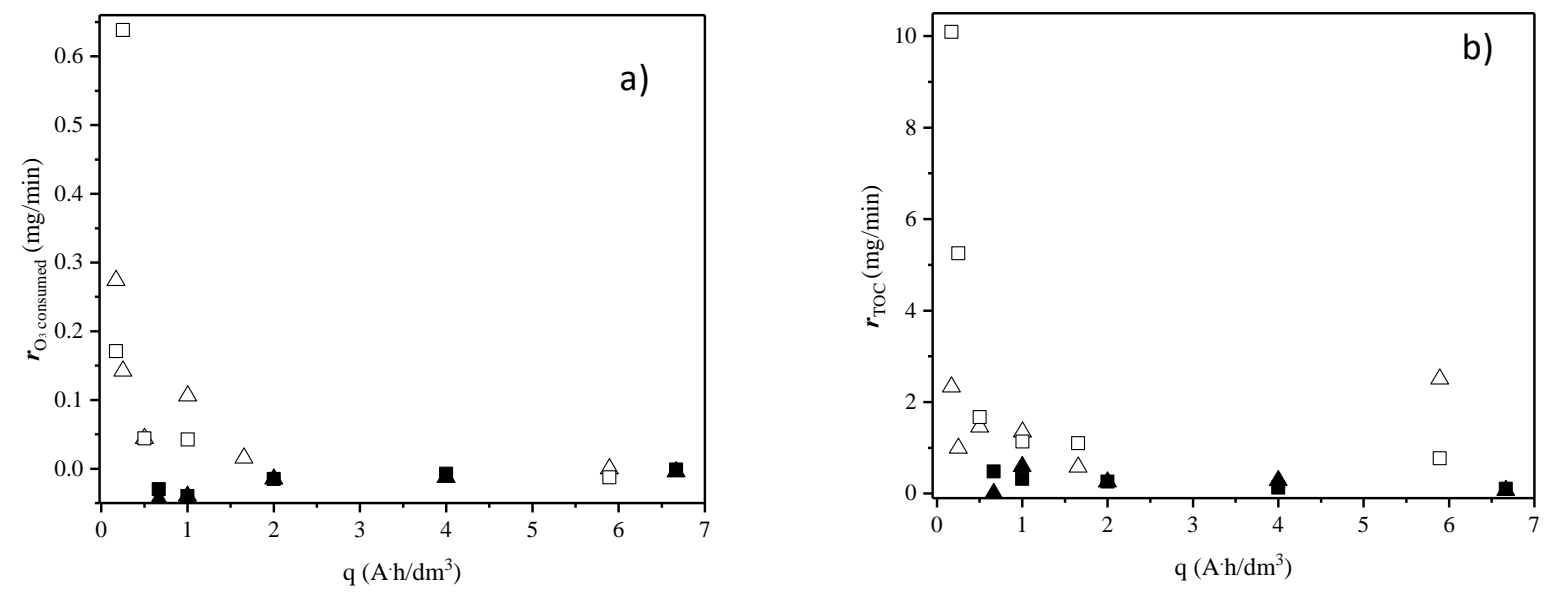
Figure 7. Consumed ozone rate (a) and mineralization rate of $\mathrm{CP}$ during ozone electrogeneration in discontinuous (empty symbol) and continuous (full symbols) mode.

For comparison purposes, same characterization of the net ozone dissolved in the waste and used for oxidation is carried out in the PEM electrolyzers, and ozonator. Results are shown in Figure 8, which shows the rate which ozone is being consumed and dissolved in the presence and absence of the $\mathrm{CP}$ as a function of the time for discontinuous and continuous processes. The net rate of ozone dissolution is higher in discontinuous mode until $1 \mathrm{~A} \cdot \mathrm{h} / \mathrm{dm}^{3}$, then it decreases as the applied load increases. This indicates that the ozone is saturated in the solution and begins to transfer to the atmosphere. The average rate of ozone production and consumption in a continuous mode tends to stabilize in electro-ozonizers after a certain number of applied loads. CabECO ${ }^{\circledR}$ cell achieves to stabilize the rates of production and consumption of ozone in a lower number of charges than $\mu \mathrm{ZON}{ }^{\circledR}$ cell and ozonator. In the particular case of the ozonator, this has a similar consumption rate in continuous and discontinuous mode. This could be due to a slow kinetic regime of the reaction of $\mathrm{CP}$ with ozone. In other words, the rate of ozone consumption depends solely on mass transport controlled by the reaction kinetics of $\mathrm{CP}$.

On the other hand, the amount of ozone that escaped from the electro-ozonizers by gas effluent was below the quantification limit of the equipment $\left(0.1 \mathrm{~g} / \mathrm{Nm}^{3}\right)$ used to measure ozone in the gas phase. 

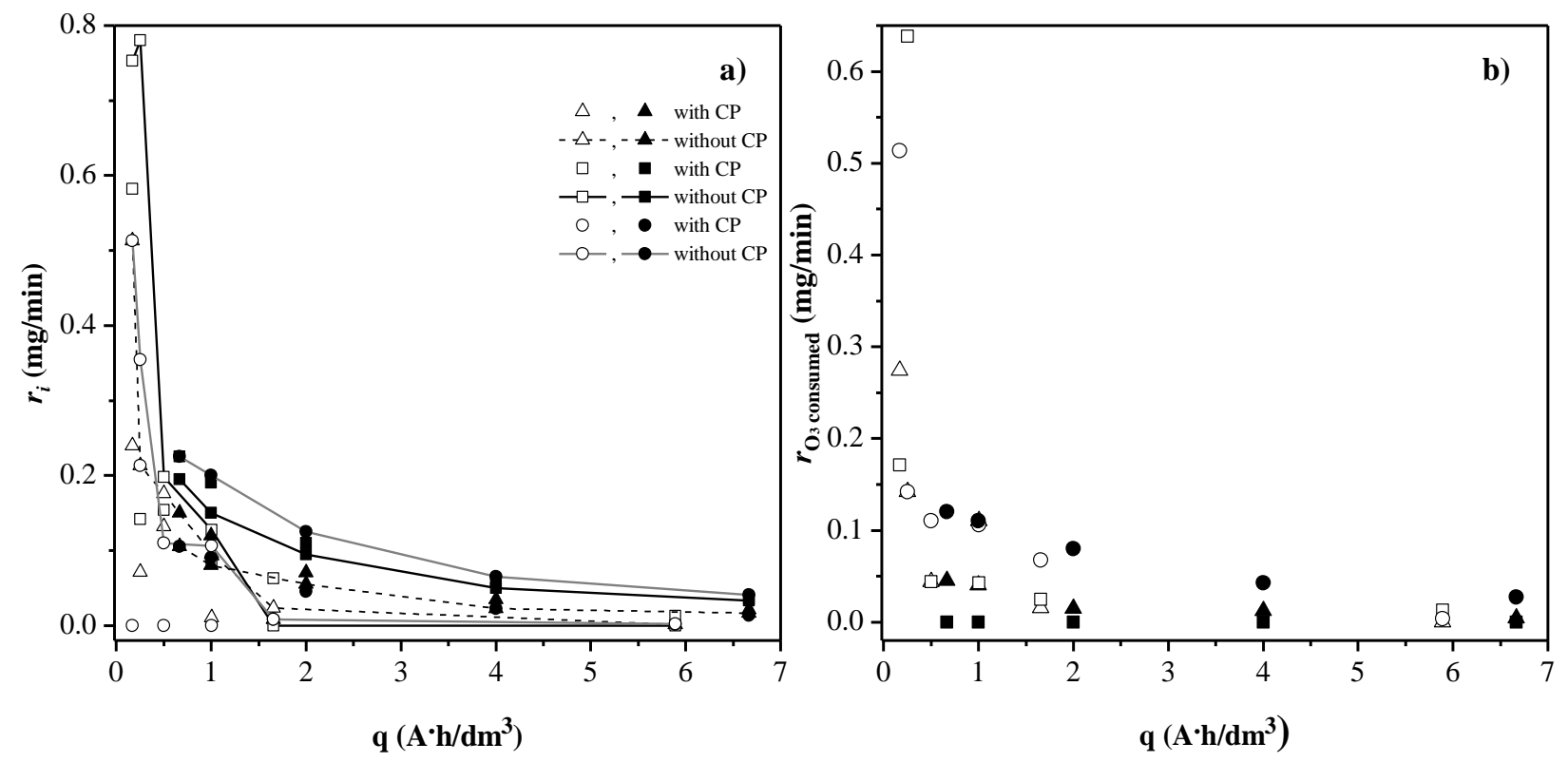

Figure 8. Ozone rates (ri) for ozone dissolved (part a) and consumption (part b), for discontinuous (empty symbol) and continuous (full symbols) conditions. $\mu \mathrm{ZON} ®$ (triangle), CabECO® (square) and ozonator (circle).

Taking into account the energy consumption of each ozonizer evaluated and the average net production rates of ozone in discontinuous and continuous mode, Table 1 was made. In this table the $\mathrm{g}$ of ozone for $\mathrm{kWh}$ produced by each systems are compared in terms of the maximum rate measured and the average during the test carried out. It can be observed that the highest electric power consumption in ozone production was discontinuous mode, this could be caused for the ozone loss by to reactions over electrodes, with other oxidizing species in solution and to the transfer of ozone into the atmosphere, causing low values of the dissolved ozone, mineralization and net rate of ozone production for PEM electrolyzers in discontinuous mode. In the case of the ozonator, typically, this type of equipment requires high energy consumption to be used (see Table 1). 
On the other hand, the continuous mode $\mu \mathrm{ZON} ®$ cell has a lower electrical consumption in the mineralization of $\mathrm{CP}$, but a higher consumption of electrical energy in the ozone generation than $\mathrm{CabECO}{ }^{\circledR}$ cell. A possible explanation for this behavior may be the high current density and overpotential of $\mu \mathrm{ZON} ®$ that increased the number of oxidizing species that will assist in the mineralization of $\mathrm{CP}$ and at the same time will react with ozone by decreasing the amount of ozone dissolved in solution.

Table 1: Energy consumption of $\mathrm{CabECO} \AA$ and $\mu \mathrm{ZON} ®$ cells in the generation of ozone and removal of TOC.

\begin{tabular}{|c|c|c|c|c|}
\hline & $\begin{array}{l}\text { Operating } \\
\text { conditions }\end{array}$ & $\begin{array}{c}\text { ECozone } \\
\mathbf{k W h} / \mathbf{g ~ O}_{3}\end{array}$ & $\begin{array}{c}\text { EC }_{\text {TOC }} \\
\mathrm{kWh} / \mathrm{g} \text { TOC }\end{array}$ & $\begin{array}{l}\text { Power consumption } \\
\qquad(k W) \times 10^{3}\end{array}$ \\
\hline \multirow[b]{2}{*}{ } & discontinuous & 23.60 & 2.13 & 18.47 \\
\hline & continuous & 0.208 & 2.02 & 15.20 \\
\hline \multirow[b]{2}{*}{ CabECO® } & discontinuous & 5.43 & 1.47 & 6.91 \\
\hline & continuous & 0.064 & 3.17 & 8.63 \\
\hline \multirow[b]{2}{*}{ Ozonator } & discontinuous & 54.79 & 111.54 & 45.00 \\
\hline & continuous & 0.618 & 4.69 & 45.00 \\
\hline
\end{tabular}

\section{Conclusions}

From this work, the following conclusions can be drawn:

- It is possible to produce ozone using PEM electrolyzers. Both commercial prototypes allow the production of significant amounts of ozone with energy efficiencies that are comparable to those of a conventional ozonator.

- In PEM electrolyzers the amount of ozone consumed is lower than the necessary for the mineralization observed indicating that other oxidation mechanisms can be happening in the system. 
- The ozone electrogeneration using $\mu \mathrm{ZON}{ }^{\circledR}$ CONDIAS cell has better behavior in the transformation and mineralization of $\mathrm{CP}$ as compared with the $\mathrm{CabECO}{ }^{\circledR}$ cell and the ozonator.

- In comparing the by-products generated during $\mathrm{CP}$ degradation by the use of the ozonator and $\mu \mathrm{ZON} \AA$ and $\mathrm{CabECO} \AA$ cells, it was identified that by the nonelectrochemical ozonator a higher concentration of acid intermediates (picolinic, 3chloropicolinic, and 6-Chloropicolinic acids) was generated, hence a low mineralization of the $\mathrm{CP}$ was achieved.

- The average ozone production available to react with organic matter and the electrical efficiency in mineralization, show better performance with PEM electrolyzers than with the ozonator in similar operating conditions.

\section{Acknowledgments}

Financial support from the Spanish Agencia Estatal de Investigación through project CTM2016-76197-R (AEI/FEDER, UE) is gratefully acknowledged. This work are also first results of the Project PID2019-107271RB-I00, continuation of the CTM2016-76197-R. Lara-Ramos thank Universidad del Valle and COLCIENCIAS (Ph.D. scholarships 727) and to the CI-2987 project with the Universidad del Valle.

\section{Literature Cited}

[1] Bebelis, S., Bouzek, K., Cornell, A., Ferreira, M. G. S., Kelsall, G. H., Lapicque, F., de Leon, C. P., Rodrigo, M. A., Walsh, F. C., Highlights during the development of electrochemical engineering. Chemical Engineering Research \& Design 2013, 91, 19982020 DOI: 10.1016/j.cherd.2013.08.029. 
[2] Dewil, R., Mantzavinos, D., Poulios, I., Rodrigo, M. A., New perspectives for Advanced Oxidation Processes. Journal of Environmental Management 2017, 195, 93-99 DOI: 10.1016/j.jenvman.2017.04.010.

[3] Barrera-Diaz, C., Canizares, P., Fernandez, F. J., Natividad, R., Rodrigo, M. A., Electrochemical Advanced Oxidation Processes: An Overview of the Current Applications to Actual Industrial Effluents. Journal of the Mexican Chemical Society 2014, 58, 256-275. [4] Agustina, T. E., Ang, H. M., Vareek, V. K., A review of synergistic effect of photocatalysis and ozonation on wastewater treatment. Journal of Photochemistry and Photobiology C-Photochemistry Reviews 2005, 6, 264-273 DOI:

10.1016/j.jphotochemrev.2005.12.003.

[5] Palit, S., An overview of ozonation associated with nanofiltration as an effective procedure in treating dye effluents from textile industries with the help of a bubble column reactor. Int J Chem Sc 2012, 10, 27.

[6] Gomes, J. F., Leal, I., Bednarczyk, K., Gmurek, M., Stelmachowski, M., Diak, M., Emilia Quinta-Ferreira, M., Costa, R., Quinta-Ferreira, R. M., Martins, R. C.,

Photocatalytic ozonation using doped $\mathrm{TiO} 2$ catalysts for the removal of parabens in water. Science of the Total Environment 2017, 609, 329-340 DOI:

10.1016/j.scitotenv.2017.07.180.

[7] Im, D., Nakada, N., Fukuma, Y., Kato, Y., Tanaka, H., Performance of combined ozonation, coagulation and ceramic membrane process for water reclamation: Effects and mechanism of ozonation on virus coagulation. Separation and Purification Technology 2018, 192, 429-434 DOI: 10.1016/j.seppur.2017.10.044.

[8] Sires, I., Brillas, E., Oturan, M. A., Rodrigo, M. A., Panizza, M., Electrochemical advanced oxidation processes: today and tomorrow. A review. Environmental Science and Pollution Research 2014, 21, 8336-8367 DOI: 10.1007/s11356-014-2783-1.

[9] Martínez-Huitle, C. A., Rodrigo, M. A., Sirés, I., Scialdone, O., Single and Coupled Electrochemical Processes and Reactors for the Abatement of Organic Water Pollutants: A Critical Review. Chemical Reviews 2015, 115, 13362-13407 DOI:

10.1021/acs.chemrev.5b00361.

[10] Martinez-Huitle, C. A., Brillas, E., Decontamination of wastewaters containing synthetic organic dyes by electrochemical methods: A general review. Applied Catalysis BEnvironmental 2009, 87, 105-145 DOI: 10.1016/j.apcatb.2008.09.017.

[11] Brillas, E., Martínez-Huitle, C. A., Decontamination of wastewaters containing synthetic organic dyes by electrochemical methods. An updated review. Applied Catalysis B: Environmental 2015, 166-167, 603-643 DOI: 10.1016/j.apcatb.2014.11.016.

[12] Rodrigo, M. A., Oturan, N., Oturan, M. A., Electrochemically Assisted Remediation of Pesticides in Soils and Water: A Review. Chemical Reviews 2014, 114, 8720-8745 DOI: 10.1021/cr500077e.

[13] Polcaro, A. M., Mascia, M., Palmas, S., Vacca, A., Electrochemical degradation of diuron and dichloroaniline at BDD electrode. Electrochimica Acta 2004, 49, 649-656 DOI: 10.1016/j.electacta.2003.09.021.

[14] Steter, J. R., Dionisio, D., Lanza, M. R. V., Motheo, A. J., Electrochemical and sonoelectrochemical processes applied to the degradation of the endocrine disruptor methyl paraben. Journal of Applied Electrochemistry 2014, 44, 1317-1325 DOI: 10.1007/s10800014-0742-7.

[15] Bernal-Martinez, L. A., Barrera-Diaz, C., Natividad, R., Rodrigo, M. A., Effect of the continuous and pulse in situ iron addition onto the performance of an integrated 
electrochemical-ozone reactor for wastewater treatment. Fuel 2013, 110, 133-140 DOI: 10.1016/j.fuel.2012.11.067.

[16] Foti, G., Gandini, D., Comninellis, C., Perret, A., Haenni, W., Oxidation of organics by intermediates of water discharge on $\mathrm{IrO} 2$ and synthetic diamond anodes.

Electrochemical and Solid State Letters 1999, 2, 228-230.

[17] Fryda, M., Herrmann, D., Schafer, L., Klages, C. P., Perret, A., Haenni, W.,

Comninellis, C., Gandini, D., Properties of diamond electrodes for wastewater treatment.

New Diamond and Frontier Carbon Technology 1999, 9, 229-240.

[18] Canizares, P., Saez, C., Sanchez-Carretero, A., Rodrigo, M. A., Synthesis of novel oxidants by electrochemical technology. Journal of Applied Electrochemistry 2009, 39,

2143-2149 DOI: 10.1007/s10800-009-9792-7.

[19] Serrano, K., Michaud, P. A., Comninellis, C., Savall, A., Electrochemical preparation of peroxodisulfuric acid using boron doped diamond thin film electrodes. Electrochimica Acta 2002, 48, 431-436 DOI: 10.1016/s0013-4686(02)00688-6.

[20] Groenen-Serrano, K., Weiss-Hortala, E., Savall, A., Spiteri, P., Role of Hydroxyl Radicals During the Competitive Electrooxidation of Organic Compounds on a BoronDoped Diamond Anode. Electrocatalysis 2013, 4, 346-352 DOI: 10.1007/s12678-0130150-5.

[21] Panizza, M., Cerisola, G., Direct And Mediated Anodic Oxidation of Organic Pollutants. Chemical Reviews 2009, 109, 6541-6569 DOI: 10.1021/cr9001319.

[22] Bergmann, M. E. H., Rollin, J., Iourtchouk, T., The occurrence of perchlorate during drinking water electrolysis using BDD anodes. Electrochimica Acta 2009, 54, 2102-2107 DOI: 10.1016/j.electacta.2008.09.040.

[23] Bergmann, M. E. H., Iourtchouk, T., Rollin, J., The occurrence of bromate and perbromate on BDD anodes during electrolysis of aqueous systems containing bromide: first systematic experimental studies. Journal of Applied Electrochemistry 2011, 41, 1109 1123 DOI: $10.1007 / \mathrm{s} 10800-011-0329-5$.

[24] Comninellis, C., Kapalka, A., Malato, S., Parsons, S. A., Poulios, I., Mantzavinos, D., Advanced oxidation processes for water treatment: Advances and trends for R\&D. Journal of Chemical Technology and Biotechnology 2008, 83, 769-776 DOI: 10.1002/jctb.1873.

[25] Lara-Ramos, J.A., Sánchez-Gómez, K., Valencia-Rincón, D., Diaz-Angulo, J., Mueses, M., Machuca-Martínez, F. Intensification of the $\mathrm{O}_{3} / \mathrm{TiO}_{2} / \mathrm{UV}$ advanced oxidation process using a modified flotation cell. Photochemical and Photobiological Sciences 2019, 18, 920928. DOI: $10.1039 / \mathrm{c} 8 \mathrm{pp} 00308 \mathrm{~d}$

[26] Kraft, A., Stadelmann, M., Wunsche, M., Blaschke, M., Electrochemical ozone

production anodes and a solid polymer using diamond electrolyte. Electrochemistry Communications 2006, 8, 883-886 DOI: 10.1016/j.elecom.2006.02.013.

[27] De Sousa, L. G., Franco, D. V., Da Silva, L. M., Electrochemical ozone production using electrolyte-free water for environmental applications. Journal of Environmental Chemical Engineering 2016, 4, 418-427 DOI: 10.1016/j.jece.2015.11.042.

[28] De Battisti, A., Formaglio, P., Ferro, S., Al Aukidy, M., Verlicchi, P., Electrochemical disinfection of groundwater for civil use - An example of an effective endogenous advanced oxidation process. Chemosphere 2018, 207, 101-109 DOI:

10.1016/j.chemosphere.2018.05.062.

[29] Isidro, J., Llanos, J., Saez, C., Brackemeyer, D., Canizares, P., Matthee, T., Rodrigo, M. A., Can CabECO (R) technology be used for the disinfection of highly faecal-polluted 
surface water? Chemosphere 2018, 209, 346-352 DOI:

10.1016/j.chemosphere.2018.06.106.

[30] Isidro, J., Brackemeyer, D., Saez, C., Llanos, J., Lobato, J., Canizares, P., Matthee, T., Rodrigo, M. A., Operating the CabECO (R) membrane electrolytic technology in continuous mode for the direct disinfection of highly fecal-polluted water. Separation and Purification Technology 2019, 208, 110-115 DOI: 10.1016/j.seppur.2018.04.070.

[31] Christensen, P.A, Yonar, T., Zakaria, K., The Electrochemical Generation of Ozone: A Review, Ozone: Science \& Engineering, 2013, 35, 149-167 DOI:

10.1080/01919512.2013.761564 